\title{
New evidence on a cold case: trophic transmission, distribution and host-specificity in Hedruris spinigera (Nematoda: Hedruridae)
}

\author{
José L. Luque ${ }^{1}$, Fabiano M. Vieira ${ }^{2}$, Kristin Herrmann ${ }^{3}$, Tania M. King ${ }^{3}$, Robert Poulin ${ }^{3}$ and Clément Lagrue ${ }^{4}$ \\ ${ }^{1}$ Departamento de Parasitologia Animal, Universidade Federal Rural do Rio de Janeiro, Caixa Postal 74.508, CEP 23851-970 \\ Seropédica, RJ, Brasil; \\ ${ }^{2}$ Curso de Pós-Graduação em Biologia Animal, Universidade Federal Rural do Rio de Janeiro, Seropédica, RJ, Brasil; \\ ${ }^{3}$ Department of Zoology, University of Otago, P.O. Box 56, Dunedin 9054, New Zealand; \\ ${ }^{4}$ Laboratoire d'Ecologie Fonctionnelle (EcoLab, CNRS UMR 5245), 29 Rue Jeanne Marvig, BP 24349, 31055 Toulouse cedex 4, \\ France
}

\begin{abstract}
The life cycle of Hedruris spinigera Baylis, 1931 (Nematoda: Hedruridae) is determined here with the first formal identification of the parasite's intermediate host: the crustacean amphipod Paracorophium excavatum Thomson. Adult H. spinigera are redescribed from specimens collected from the stomach of fishes, Retropinna retropinna (Richardson) and Aldrichetta forsteri (Valenciennes), from Lake Waihola, New Zealand. Immature adults of the parasite collected from intermediate hosts (P. excavatum) are also described for the first time. The prevalence, abundance and intensity of infection of $H$. spinigera in several fish species are quantified along with the occurrence of $P$. excavatum, the parasite's intermediate host, in fish stomach contents. Although $H$. spinigera's transmission mode (trophic transmission) and fish diet potentially expose all fish species to infection, some level of host specificity must exist as parasite prevalence, abundance and intensity of infection vary greatly between potential definitive host species. We suggest here that the anatomy of the fish digestive tract and especially that of the stomach plays an important role in host suitability for H. spinigera. While P. excavatum is the only intermediate host in Lake Waihola, H. spinigera was found in six different fish species: Aldrichetta forsteri, Galaxias maculatus (Jenyns), Retropinna retropinna, Rhombosolea retiaria Hutton, Perca fluviatilis Linnaeus and Salmo trutta Linnaeus; although typical hedrurid attachment and mating positions were observed only in $R$. retropinna and A. forsteri. The limited distribution of H. spinigera is most likely due to that of its different host species (intermediate and definitive), all inhabitants of coastal fresh and brackish waters.
\end{abstract}

Keywords: Hedruris spinigera, nematode, host specificity, parasite distribution, amphipod, fish

Hedruris Nitzsch, 1821, the only genus of the family Hedruridae (Nematoda), consists of parasites of the digestive tracts of fishes, frogs, salamanders, lizards, and turtles. Hedruris was first proposed by Nitzsch (1821) to include Hedruris androphora from intestine of Triturus cristatus (Laurenti) (Caudata, Salamandridae). Until recently and the description of a new species from Argentina (Brugni and Viozzi 2010), there were 22 documented nominal species of Hedruris distributed worldwide (Bursey and Goldberg 2000, 2007). As common characters, Hedruris species possess four complex lips, oesophagus not clearly divided into muscular and glandular portions, and the terminal end of the female is modified into an attachment or prehensile organ (Petter 1971, Hasegawa and Otsuru 1979, Anderson 2000). Species of Hedruris are distinguished on the basis of the number and arrangement of caudal papillae in the male, appearance of eggs in females and morphology of cephalic structures, spicules and female caudal hook (Baker 1986, Hasegawa
1989, Bursey and Goldberg 2000, 2007). Currently, the development cycles of only three species have been investigated: $H$. androphora Nitzsch, 1821, H. ijimai Morishita, 1926 and H. suttonae Brugni et Viozzi, 2010 (Petter 1971, Hasegawa and Otsuru 1979, Brugni and Viozzi 2010).

In New Zealand, there have been very few studies of larval nematodes, and nematode development cycles are seldom described (Moravec et al. 2003). For example, Hedruris spinigera Baylis, 1931 is a common freshwater parasite typically found in the stomach of fish where the larger female attaches itself deeply into the stomach epithelium using a recurved hook in its tail (Fig. 1A, Clark 1978, McDowall 1990). The smaller male lacks the attachment structure and moves freely in the stomach lumen until it finds a female already attached to the host and curls around her body (Fig. 1B, Clark 1978, Jellyman 1989). Taxonomically, Hedruris spinigera is most similar to H. bryttosi Yamaguti, 1935, H. miyakoensis Hasegawa,

Address for correspondence: C. Lagrue, Laboratoire d'Ecologie Fonctionnelle (EcoLab, CNRS UMR 5245), 29 Rue Jeanne Marvig, BP 24349 , 31055 Toulouse cedex 4, France. Phone: +33 (0)5 622699 65; Fax: +33 (0)5 622699 99; E-mail: clement.lagrue@gmail.com 


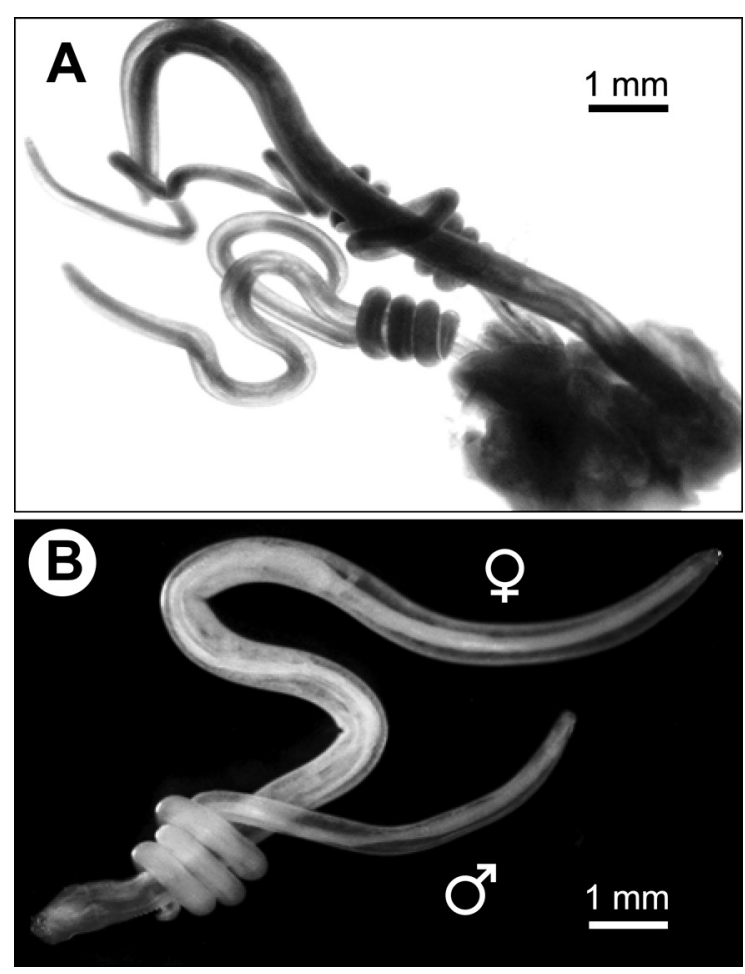

Fig. 1. Hedruris spinigera Baylis, 1931, light microscopy of mature adults from fish definitive hosts. A - large female with tail end anchored about two-third through the fish host stomach epithelium, smaller males in the background; B - mature male and female shown in typical attachment position with male coiled around tail end of female. Specimens were still attached to fish stomach epithelium when fixed in $70 \%$ ethanol.

1989 and H. hanleyae Bursey et Goldberg, 2000 with males exhibiting 10 pairs of papillae and females producing nonmammillated eggs. Nevertheless, $H$. spinigera has one pair of precloacal papillae and one pair of adcloacal papillae while $H$. bryttosi lacks precloacal papillae (Yamaguti 1935). Similarly to H. spinigera, H. miyakoensis has one (or two) pair of precloacal papillae (Hasegawa 1989) but the spicules and the anterior end are morphologically different from those of $H$. spinigera. Finally, $H$. hanleyae has two pairs of precloacal papillae (Bursey and Goldberg 2000).

Intriguingly, although $H$. spinigera is widely distributed within New Zealand and can infect a variety of fish, this parasite occurs only near coastal areas, especially in brackish waters (Stokell 1936, Hine 1978, Jellyman 1989). No satisfactory explanation has ever been proposed for this geographical restriction although fish diet and the identity of intermediate host species have been hypothesized to determine the distribution and abundance of $H$. spinigera in fish hosts. Nevertheless, H. spinigera's intermediate host(s) has never been clearly identified although several species of crustacean are assumed to be suitable (Stokell 1936, Griffiths 1976a, Jellyman 1989).

Thus, the key to understanding $H$. spinigera's life cycle and its dynamic of infection in fish definitive hosts lies in the consideration of fish diet and the identification of the intermediate host(s). During recent investigations into the parasites of freshwater fish in southern New Zealand, adult $H$. spinigera were observed in the digestive tract of several fish species, and infections were linked to the consumption of a common brackish water crustacean, the amphipod Paracorophium excavatum Thomson. Previously, Luque et al. (2007) described parasitic nematode larvae from $P$. excavatum from the same location and classified these as Hysterothylacium sp.; here, we critically reexamine this identification in the light of morphological and molecular data on adult $H$. spinigera. The nematode's sexually mature adults from definitive hosts and immature adults (i.e. larval stages) from intermediate hosts are matched formally for the first time using molecular evidence and described morphologically; further, the life cycle is determined and host specificity of the parasite is discussed from the results on fish diet and $H$. spinigera prevalence and abundance in the different fish species.

\section{MATERIALS AND METHODS}

The parasites were found in several samples of the amphipod Paracorophium excavatum and different fish species collected from the same location. Samples were taken between November 2008 and February 2009 (Austral summer) along a short stretch of the shore of Lake Waihola $\left(46^{\circ} 01^{\prime} \mathrm{S}, 170^{\circ} 05^{\prime} \mathrm{E}\right)$, near Dunedin, South Island, New Zealand. Lake Waihola is a shallow, coastal lake situated $10 \mathrm{~km}$ from the Pacific Ocean and influenced twice daily by a fresh to brackish tidal input, depending on tides and river flow (Hall and Burns 2002). Only one other amphipod species is present in Lake Waihola, Paracalliope fluviatilis Thomson. However, despite extensive sampling, no $H$. spinigera infection was ever found in this species (Lagrue and Poulin 2008a, b). It is also important to note that although Hedruris species occur commonly in amphibians (Chandler 1919, Hasegawa and Otsuru 1979, Anderson 2000, Bursey and Goldberg 2000), these potential definitive hosts are totally absent from Lake Waihola. New Zealand amphibian fauna is naturally very poor and comprises only few species of highly specialized and geographically restricted frogs of the genus Leiopelma (Bell 1978, Towns and Daugherty 1994).

Nine samples of 150 P. excavatum (1350 individuals in total) were collected at regular intervals during the sampling period. Amphipods were captured using a push-net (500 $\mu \mathrm{m}$ mesh size) and dredging the surficial sediment where P. excavatum burrows. The retained sediment with associated organisms was placed in sorting trays from which $P$. excavatum individuals were collected (Schnabel et al. 2000). Amphipods were kept alive in plastic containers filled with local water and brought back to the laboratory for later dissection. Fish were collected weekly during the sampling period using gillnets constructed by Oy Lindeman $\mathrm{Ab}$ of Finland and a standard purse seine net. For gillnetting, three $25 \mathrm{~m}$ long multi-mesh nets covering the whole water column were used. These gillnets were benthic weighted sets with top floats, $1.5 \mathrm{~m}$ high and comprised five panels of 13, 25, 38, 56 and $70 \mathrm{~mm}$ meshes, $5 \mathrm{~m}$ long each (Appelberg 2000). Gillnets being ineffective for catching fish less than $50 \mathrm{~mm}$ long, a seine net was used to capture the smaller fish species and/or juvenile specimens that could not be caught with gillnets (Tischler et al. 
2000). The seine net was $20 \mathrm{~m}$ long and $1.5 \mathrm{~m}$ high, with a $5 \mathrm{~mm}$ mesh diameter, and dragged by two people along the lake shore. Again, the net covered the whole water column at all times so no fish could escape underneath or above. After capture, fish (see Table 1 for details) were killed immediately to stop the digestion process and stored on ice until dissection to preserve internal tissues and parasites for future identification.

Data on $H$. spinigera occurrence and numbers in amphipod and fish hosts were recorded during dissection and used to determine the parasite's prevalence (proportion of infected hosts), mean abundance (mean number of parasites per host) and mean intensity (mean number of parasites per infected host) of infection in the different host species. Parasitological terminology applied throughout the article follows the recommendations of Bush et al. (1997). Also, to evaluate the exposure of each fish species to this parasite, stomach contents were examined to determine the importance of the intermediate host (P. excavatum) of $H$. spinigera in the diet of the different fish species. Note that fishes were identified to species according to McDowall (1990) and fish scientific names follow FishBase (Froese and Pauly 2000).

Individual nematodes from the amphipod host $P$. excavatum (larval and immature adult stages) and from the fish hosts (adult stage of $H$. spinigera) Retropinna retropinna (Richardson) (Osmeriformes: Retropinnidae) and Aldrichetta forsteri (Valenciennes) (Mugiliformes: Mugilidae) were fixed and stored in 70\% ethanol for subsequent morphological analyses and taxonomic description. For light microscopy, the specimens were cleared in Amann's lactophenol (1:1:2:1 phenol: lactic acid: glycerine: water) in which they were kept during measuring and drawing. Drawings were made with the aid of a drawing tube attached to a light microscope. Measurements are given in micrometres $(\mu \mathrm{m})$ as the mean followed by the size range in parentheses, with the standard deviation or the standard error for large samples.

Identification and classification of the specimens to the generic level follow Chabaud (1974, 1975), and to the specific level follow Baylis (1931) and Bursey and Goldberg (2000, 2007). Voucher specimens (adults from fish definitive hosts and immature adults from amphipod intermediate hosts) are deposited in the Instituto Oswaldo Cruz Helminthological Collection (CHIOC), Rio de Janeiro, Brazil and in the collection of the Otago Museum, Dunedin, New Zealand, all stored in $70 \%$ ethanol (Luque et al. 2007).

Eight individual nematodes were stored separately in $95 \%$ ethanol for subsequent DNA extraction and genotyping: 4 adult specimens, one from each of four $R$. retropinna stomachs and 4 larval specimens from four different amphipods ( $P$. excavatum) were isolated in Eppendorf tubes. DNA was extracted from the nematodes using $400 \mu \mathrm{l}$ of $5 \%$ Chelex solution (BioRad) containing $0.1 \mathrm{mg} / \mathrm{ml}$ Proteinase $\mathrm{K}$ (Roche), incubated at $60^{\circ} \mathrm{C}$ overnight, followed by $10 \mathrm{~min}$ at $90^{\circ} \mathrm{C}$. Approximately $900 \mathrm{bp}$ of $18 \mathrm{~S}$ and $400 \mathrm{bp}$ of the third domain of $28 \mathrm{~S}$ (D3) were amplified using the primers Nem $18 \mathrm{~S}$ F and Nem 18S R (Floyd et al. 2005) and D3a and D3b (Sharpe 1999), respectively, on each of the eight specimens. Each $25 \mu \mathrm{l}$ PCR contained $0.5 \mu \mathrm{M}$ of each primer, $0.8 \mathrm{mM}$ dNTPs, $1.5 \mathrm{mM} \mathrm{MgCl}, 1$ unit BioTaq Red (Bioline) and $1 \mu \mathrm{l}$ of extracted DNA. PCR amplifications were performed using an Eppendorf Mastercycler ep gradient $\mathrm{S}$ under the same conditions for both genes, consisting of $94^{\circ} \mathrm{C}$ for $3 \mathrm{~min}$, followed by 45 cycles of $94^{\circ} \mathrm{C}$ for $30 \mathrm{~s}, 45^{\circ} \mathrm{C}$ for $30 \mathrm{~s}$ and $72^{\circ} \mathrm{C}$ for $60 \mathrm{~s}$, with a final extension of $72^{\circ} \mathrm{C}$ for $240 \mathrm{~s}$. Ampli- fied DNA was purified using an Invitrogen PureLink PCR purification kit and quantified using a Nanodrop spectrophotometer. Sequencing was done by the Allan Wilson Centre sequencing service (Massey University, Palmerston North, New Zealand) using an ABI 3730 DNA Analyzer. Sequences were edited and aligned using Sequencher (GeneCodes Corporation) then compared to the NCBI database using BLAST to search for genetic matches (Altschul et al. 1990).

\section{RESULTS}

\section{Morphological analyses and taxonomic description}

Hedruris spinigera Baylis, 1931

Mature adults (from fish hosts)

Fig. 2A-G

General: Anterior end with 2 lateral pseudolabia and 2 median lips. Lateral pseudolabia each bearing 2 pairs of papillae and one amphid. Median lips irregular. Buccal cavity thin-walled. Oesophagus not clearly divided into muscular and glandular portions; anterior end with sclerotized annulus; junction with valved intestine. Cuticle thick, with irregular transverse folds and slight transverse striations. Female with posterior prehensile sclerotized hook.

Male (based on 9 adult specimens): Total length 7500 (6580-9170); maximum body width 177 (170-194); width at level of excretory pore 137 (125-151). Head 77 (7286) long. Posterior one-third of body in 2-3 permanent coils. Oesophagus cylindrical, 1350 (1260-1470) long. Nerve ring 183 (135-221), excretory pore 434 (406-463) from anterior extremity. Tail 226 (180-254) long, sharply pointed. Ten pairs of posterior subventral papillae; 1 pair precloacal; 1 pair adcloacal (at sides of cloacal opening); 8 pairs postcloacal (7 pedunculate subventral and 1 sessile lateral). Precloacal subventral surface with rows of rectangular, scale-like bosses extending from near cloaca anteriorly. Spicules 200 (181-219), strongly cuticularized, fused in distal two-fifths.

Female (based on 10 adult specimens): Total length 10120 (7960-12280); maximum body width 404 (346434); narrow anteriorly, head 89 (85-94) long; width at excretory pore 212 (181-227), posterior end swollen. Oesophagus 1900 (1820-2070) long. Nerve ring 241 (208270), excretory pore 491 (386-559) from anterior extremity. Vulva 1220 (1120-1290), anus $388(351-415)$ from posterior end. Prodelphic uterus leads to a single ovijector that joins common trunk of uterus. Ovaries thin, tapering tubes that coil about anterior portion of digestive tract but not reaching oesophageal-intestinal junction level. In gravid specimens, egg-filled uteri occupy entire body cavity. Tail curved dorsally, formed into a sucker-like apparatus armed with large sclerotized hook 112 (105-121) long. Eggs $28.5 \pm 2.4$ (22.5-33.3) long, $13.1 \pm 1.8$ (1116) wide (mean \pm S.D.; $\mathrm{n}=30$ ), without lateral "mammillae", cylindrical, operculated at the poles, containing fully developed larva. 

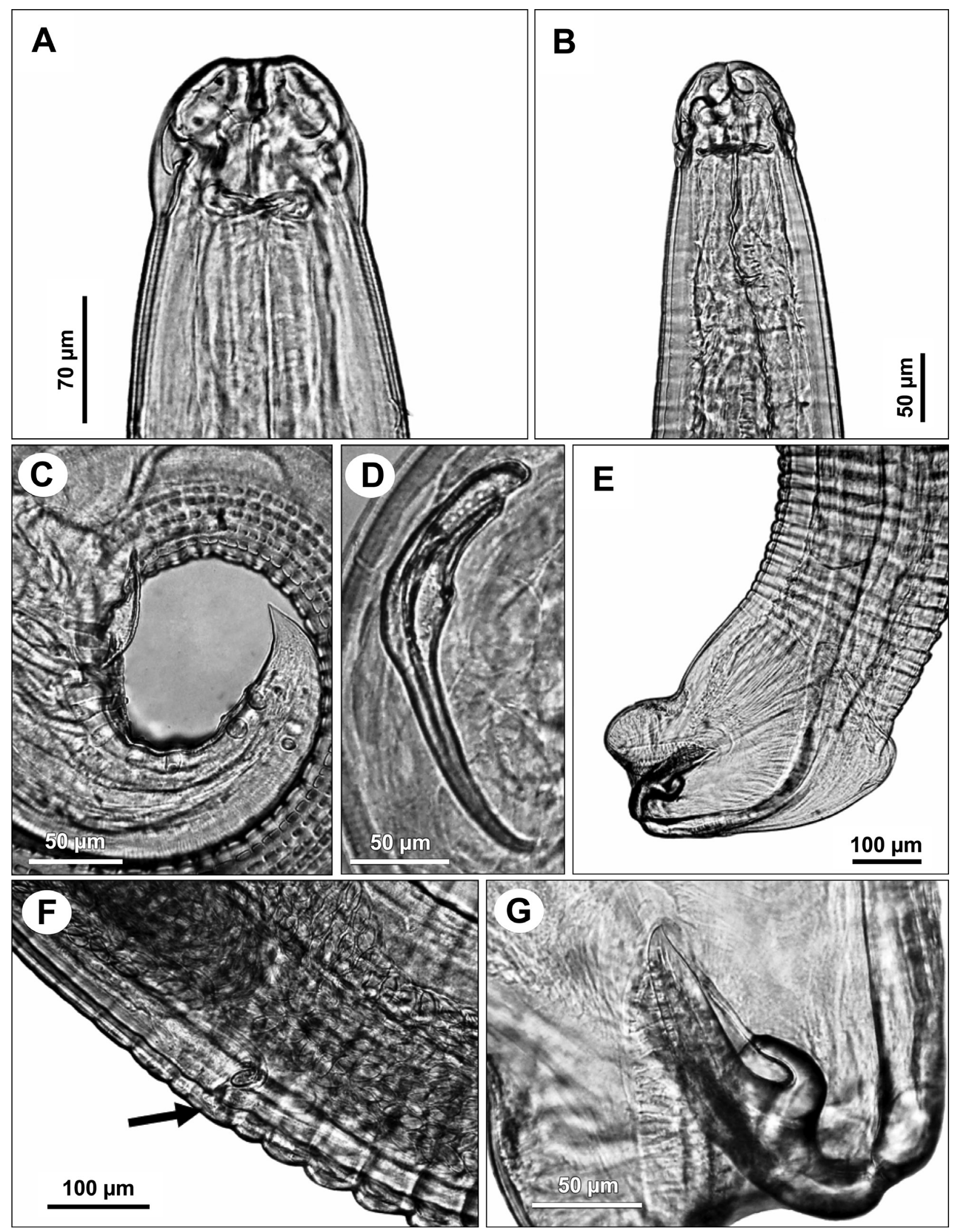

Fig. 2. Hedruris spinigera Baylis, 1931, light microscopy of mature adults from fish definitive hosts. A-male, anterior end of body, ventral view; B - female, anterior end of body, lateral view; C - male, posterior end, lateral view; D - male, spicule, lateral view; $\mathbf{E}$ - female, posterior end, lateral view; $\mathbf{F}$ - female, vulva (indicated by arrow) and terminal portion of vagina, eggs, lateral view; $\mathbf{G}$ - female, tail hook, lateral view. 
Host: Retropinna retropinna (Richardson) (Osmeriformes: Retropinnidae) and Aldrichetta forsteri (Valenciennes) (Mugiliformes: Mugilidae) were the only hosts containing females of the parasite attached to host gastric tissues and males coiled around the females in mating position. However, four other species contained unattached live worms; Galaxias maculatus (Jenyns), Rhombosolea retiaria Hutton, Perca fluviatilis Linnaeus and Salmo trutta Linnaeus.

Site of infection: Stomach is the only site of attachment for female specimens, but the parasite can also be found free-living (i.e. unattached) in the intestine and rectum of fish hosts.

L o c a lity: Lake Waihola $\left(46^{\circ} 01^{\prime} \mathrm{S}, 170^{\circ} 05^{\prime} \mathrm{E}\right)$, South Island, New Zealand.

Prevalence and Intensity: Depending on the host species (see Table 2).

Deposition of voucher specimens: Six adult male and six adult female specimens (Instituto Oswaldo Cruz Helminthological Collection, Brazil, CHIOC No. 35669 and 35670 for males and females respectively).

\section{Immature adults (in amphipod host) Fig. 3A-D}

General: Morphological characteristics of immature adults similar to mature adults from fishes, except by their smaller size and absence of eggs.

Male (based on 3 adult immature specimens): Total length 6670 (5580-7770); maximum body width 171 (165-174); width at level of excretory pore 133 (129-135). Head 57 (54-63) long. Oesophagus $1340(1280-1410)$ long. Nerve ring $255(\mathrm{n}=1)$, excretory pore $405(359-$ 437) from anterior extremity. Tail 303 (277-347) long. Spicules 185 (119-230) long.

Female (based on 3 adult immature specimens): Total length 7290 (5640-8340); maximum body width 303 (301-306); head 74 (68-77) long; width at excretory pore level 169 (117-171). Oesophagus 1750 (1430-2120) long. Nerve ring 275 (216-334), excretory pore 509 (387-686) from anterior extremity. Vulva 906 (815-984), anus 415 (396-443) from posterior end. Sclerotized caudal hook 129 (124-133) in length.

Intermediate host: Paracorophium excavatum Thomson (Amphipoda: Corophiidae) is the only intermediate host species recognized at the study site.

Site of infection: Haemocoelomic cavity. Worms coiled or folded tightly but not encysted.

L o c a lity: Lake Waihola $\left(46^{\circ} 01^{\prime} \mathrm{S}, 170^{\circ} 05^{\prime} \mathrm{E}\right)$, South Island, New Zealand.

Prevalence and intensity: Between 2.7 and $14.7 \%$ $($ mean \pm S.E. $=7.3 \pm 1.3)$ of hosts were infected, depending on the sample ( $\mathrm{n}=150$ P. excavatum per sample), usually with 1 worm $($ mean \pm S.E. $=1.11 \pm 0.03)$, but sometimes 2 and exceptionally 3 (one occurrence) H. spinigera individuals were found.

Deposition of voucher specimens: Three immature adult males and 6 larval specimens (Otago Museum, New Zealand, collection No. IV16246 to IV16254). Two immature adult females and two immature adult males
(Instituto Oswaldo Cruz Helminthological Collection, Brazil, CHIOC No. 35671).

\section{Genetic analyses}

Up to $755 \mathrm{bp}$ of $18 \mathrm{~S}$ and 317 bases of $28 \mathrm{~S}$ were sequenced for each individual and the 8 sequences (4 sexually mature adults and 4 immature adults of $H$. spinigera) were submitted to the GenBank database (GenBank Acc. Nos. HM484336 to HM484351). All sequences were identical and a BLAST search confirmed the correct gene regions had been amplified. Consequently, all specimens (4 adults and 4 immature adults) can be considered as being of the same species. There were no identical matches in NCBI for either sequence. For 18S, the closest matches were to species in the order Spirurida (90-92\% identity); Turgida torresi (Spirurida: Physalopteridea, GenBank Acc. No. EF180069) and Physaloptera turgida (Spirurida: Physalopteridea, GenBank Acc. No. DQ503459). Spirurid nematodes are numerous and widespread obligatory gastrointestinal parasites of vertebrates (Stunkard 1953, Chabaud and Bain 1994). The 28S (D3) sequence showed much weaker matches and also lower coverage. The top two matches were also to spirurid nematodes; Cystidicola farionis (Cystidicolidae, GenBank Acc. No. AY161299) and Cystidicola stigmatura (Cystidicolidae, GenBank Acc. No. AY161298).

\section{Hedruris spinigera prevalence, abundance and intensity of infection in fish hosts}

Fish from 7 different species were captured in Lake Waihola during the sampling period: Aldrichetta forsteri (Valenciennes), Galaxias maculatus (Jenyns), Gobiomorphus cotidianus McDowall, Retropinna retropinna (Richardson), Rhombosolea retiaria Hutton, Perca fluviatilis Linnaeus and Salmo trutta Linnaeus (see Table 1 for details). Perca fluviatilis and S. trutta were introduced from Europe and are now widespread and abundant in New Zealand (Thompson 1922).

Gobiomorphus cotidianus was the only fish species free of $H$. spinigera (Table 2). At least some individuals of the remaining species contained the nematode in their digestive tract, although infection parameters of $H$. spinigera varied greatly between host species (Table 2). The prevalence $(93.1$ and $46.9 \%$ ), abundance (mean \pm S.E.; $29.2 \pm 8.7$ and $12.1 \pm 7.5$ ) and intensity (mean \pm S.E.; $31.4 \pm 8.9$ and $25.9 \pm 10.6$ ) of $H$. spinigera were clearly higher in A. forsteri and R. retropinna, respectively, than in any other fish species (Table 2). Although H. spinigera's prevalence varied between 5.9 and $39.1 \%$ in the other fish host species, the numbers of nematode individuals per host were clearly lower than in $A$. forsteri and $R$. retropinna (Table 2). More importantly, A. forsteri and $R$. retropinna were the only fish species in which $H$. spinigera attained full size and maturity, and where female $H$. spinigera established and attached to the stomach epithelium 


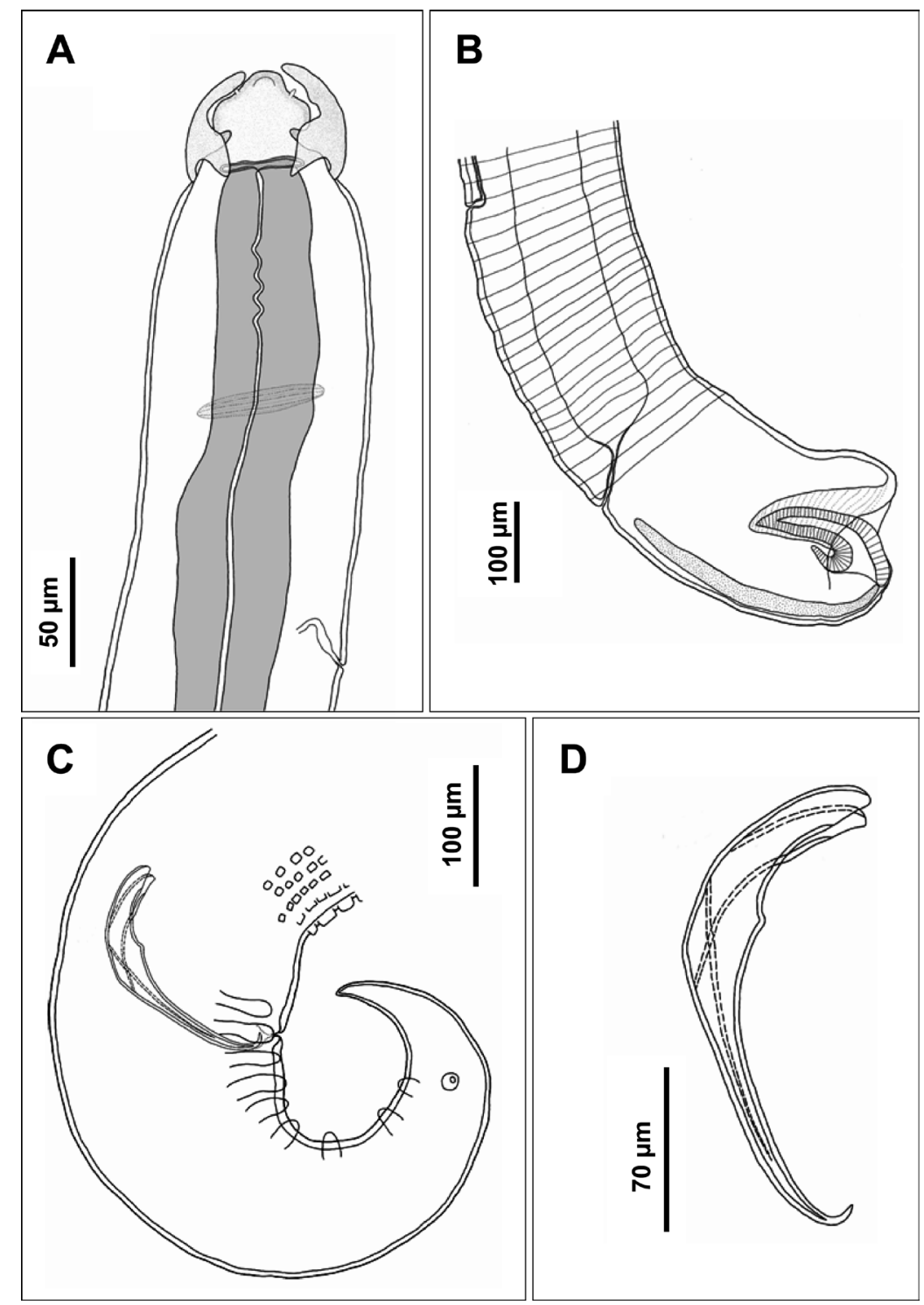

Fig. 3. Hedruris spinigera Baylis, 1931, immature adults from amphipod intermediate hosts. A - female, anterior end, lateral view; $\mathbf{B}$ - female, posterior end, lateral view; $\mathbf{C}$ - male, posterior end, lateral view; D - male, spicule, lateral view.

with males coiled around them in mating position. In no other fish species, potential definitive hosts, were female parasites found attached or males associated with females in the typical mating position.

While $P$. excavatum was found in the diet of all fish species, occurrence and abundance of the amphipod intermediate host in fish stomach contents are also highly variable (Table 2). Interestingly, $A$. forsteri and $R$. retropinna, which are the most heavily $H$. spinigera-infected species, were not the main consumers of $P$. excavatum, the intermediate host of $H$. spinigera (Table 2). Also, while the prevalence of $H$. spinigera was $0 \%$ in $G$. cotidianus, $17.1 \%$ of these fish contained $P$. excavatum in their stomach and could have been exposed to the parasite. The bottom-dwelling $R$. retiaria feeds heavily on $P$. excavatum, as indicated by the results in Table 2, but does not seem to be a very suitable host for $H$. spinigera.

\section{DISCUSSION}

Adult specimens of Hedruris spinigera were adequately described by Baylis (1931). Here, the mature adults of $H$. spinigera display morphological characteristics consistent with the original species description although adult males described in this study have smaller spicules, and adult females have smaller tail hook and eggs, when compared to the specimens described previously from Lake Ellesmere $\left(43^{\circ} 47^{\prime} \mathrm{S}, 172^{\circ} 23^{\prime} \mathrm{E}\right)$, a brackish costal lake near Christchurch, South Island, New Zealand (Baylis 1931). Unlike other helminths, H. spinigera preferentially attaches to the stomach epithelium of fish definitive hosts and more specifically in the pyloric region (Hine 1980). Therefore, individuals observed in the intestine and rectum of fish are likely to be rapidly passed out. Consequently, lower H. spinigera prevalence, mean abundance and/ 
Table 1. Fish species sampled in Lake Waihola with the sample size $(n=$ number of fish dissected), and body length (mean \pm S.E., with range in parentheses) given for each fish species.

\begin{tabular}{llllc}
\hline Fish species & Order & Family & $\mathrm{n}$ & Body length (mm) \\
\hline Aldrichetta forsteri & Mugiliformes & Mugilidae & 29 & $185.5 \pm 6.6(138-260)$ \\
Galaxias maculatus & Osmeriformes & Galaxiidae & 34 & $69.4 \pm 2.3(45-105)$ \\
Gobiomorphus cotidianus & Perciformes & Eleotridae & 35 & $44.4 \pm 1.5(32-72)$ \\
Perca fluviatilis & Perciformes & Percidae & 68 & $132.2 \pm 10.1(36-360)$ \\
Retropinna retropinna & Osmeriformes & Retropinnidae & 32 & $80.4 \pm 1.9(65-104)$ \\
Rhombosolea retiaria & Pleuronectiformes & Pleuronectidae & 46 & $90.5 \pm 14.3(30-356)$ \\
Salmo trutta & Salmoniformes & Salmonidae & 23 & $397.8 \pm 21.5(215-690)$ \\
\hline
\end{tabular}

Table 2. Hedruris spinigera prevalence (proportion of hosts containing the parasite), mean abundance (mean number of parasites per host examined \pm S.E.) and mean intensity (mean number of parasites per host infected \pm S.E.), and Paracorophium excavatum occurrence (proportion of fish containing the prey in their diet), mean abundance (mean number of prey per fish examined \pm S.E.) and mean intensity (mean number of prey per individual fish containing the prey in its diet \pm S.E.) in the different fish species captured in Lake Waihola.

\begin{tabular}{lccccccc}
\hline & \multicolumn{3}{c}{ Hedruris spinigera } & & \multicolumn{3}{c}{ Paracorophium excavatum } \\
\cline { 2 - 4 } \cline { 6 - 8 } Fish species & Prevalence (\%) & Abundance & Mean intensity & & Occurrence (\%) & Abundance & Mean intensity \\
\hline A. forsteri & 93.1 & $29.2 \pm 8.7$ & $31.4 \pm 8.9$ & & 34.5 & $3.4 \pm 1.2$ & $9.8 \pm 2.5$ \\
G. maculatus & 5.9 & $0.1 \pm 0.1$ & $2.0 \pm 1.0$ & & 2.9 & $0.03 \pm 0.03$ & $1.0 \pm$ n. a. \\
G. cotidianus & 0.0 & n. a. & n. a. & & 17.1 & $1.1 \pm 0.6$ & $6.7 \pm 3.0$ \\
P. fluviatilis & 14.7 & $0.2 \pm 0.0$ & $1.0 \pm$ n. a. & & 35.3 & $4.5 \pm 1.3$ & $12.7 \pm 3.0$ \\
R. retropinna & 46.9 & $12.1 \pm 7.5$ & $25.9 \pm 10.6$ & & 15.6 & $2.2 \pm 1.1$ & $13.8 \pm 4.8$ \\
R. retiaria & 26.1 & $4.6 \pm 2.2$ & $17.7 \pm 7.2$ & & 78.3 & $20.0 \pm 9.4$ & $25.5 \pm 11.8$ \\
S. trutta & 39.1 & $3.1 \pm 1.4$ & $8.0 \pm 2.9$ & & 26.1 & $16.2 \pm 13.0$ & $62.0 \pm 47.9$ \\
\hline
\end{tabular}

or mean intensity in some fish species may be due to their digestive tract not providing appropriate attachment sites to the parasite (Campos and Carbonell 1994); although other factors like gastrointestinal $\mathrm{pH}$, digestive enzymes and even specific parasite behaviour can affect parasite attachment and establishment in hosts (Rogers 1960, Irwin 1997). For example, G. cotidianus and $R$. retiaria, in contrast with other species like $A$. forsteri and $R$. retropinna which possess a well defined pylorus (Hine 1978, Horn 1989), display extremely simple alimentary canals with a poorly defined stomach that might not be adequate for $H$. spinigera establishment. In that sense, it is worth noting that, although this species was previously classified as a suitable definitive host for this parasite (Hine 1980, Jellyman 1989), H. spinigera was never recovered from G. cotidianus in Lake Waihola despite extensive sampling (Lagrue and Poulin 2008a, present study). Similarly, the U-shaped structure and very thick epithelium of the P. fluviatilis and $S$. trutta stomachs might not be suitable for H. spinigera attachment (Griffiths 1976b).

Although most fish species consumed $H$. spinigera's intermediate host and this parasite seems to be a generalist with respect to its fish hosts, it occurs either at low abundance or only temporarily in several fish species. For example, the presence of $H$. spinigera in predatory fish like Anguilla australis Richardson, Anguilla dieffenbachii Gray, S. trutta and P. fluviatilis is considered to be a secondary transfer from consumed prey fish, such as heavily infected individuals of $R$. retropinna (Stokell 1936, Griffiths 1976a, Hine 1978). However, these parasites mostly fail to attach in the new hosts and are quickly evacuated. Generally, some fish species in which $H$. spinigera is found are clearly not very suitable for the adult parasite (McDowall 1990). As suggested previously (Stokell 1936, Griffiths 1976a), and as indicated by our results (prevalence, abundance and intensity of $H$. spinigera infection), A. forsteri and $R$. retropinna seem to be the only truly suitable hosts for this parasite.

Interestingly, $A$. forsteri and $R$. retropinna are typically coastal species. Aldrichetta forsteri is mainly a marine fish but very commonly penetrates several kilometres inland into fresh or brackish water where it becomes abundant during the summer months and feeds on the available aquatic invertebrates (Eldon and Greager 1983, McDowall 1990). Retropinna retropinna populations are often anadromous, migrating from the sea to spawn in coastal freshwater systems during spring and early summer (McDowall 1990). In Lake Waihola, $R$. retropinna are most likely a mixture of anadromous and resident (non-migratory) stocks as fish densities vary greatly between summer and winter but adult fish are present all year round. Retropinna retropinna feed heavily on available benthic or pelagic invertebrate prey (Eldon and Greager 1983, McDowall 1990). The geographical distribution of these two fish species, $H$. spinigera's definitive hosts, might therefore explain why the distribution of the parasite is limited to coastal areas (Stokell 1936, Hine 1978, Jellyman 1989).

For the first time, larval stages (immature adults) and intermediate host species of $H$. spinigera are formally 
identified and matched. Genetic analyses confirmed that larval nematodes found in amphipod hosts are the same species as adult $H$. spinigera described from fish definitive hosts. Although previous studies classified the smaller amphipod Paracalliope fluviatilis as the most likely intermediate host for H. spinigera (Jellyman 1989, Hine et al. 2000), extensive sampling of this potential host species in Lake Waihola failed to find $H$. spinigera infections despite very high $P$. fluviatilis densities (Lagrue and Poulin 2008a, b). Here, the larger benthic amphipod Paracorophium excavatum was the only intermediate host identified for $H$. spinigera. The parasite must reach its definitive host through trophic transmission; i.e. when $H$. spinigera-infected P. excavatum are consumed by fish definitive hosts. Again, the distribution of $H$. spinigera, limited to coastal areas, may be partly attributed to the geographical distribution of the intermediate host $P$. excavatum, a common crustacean species from coastal lagoons and brackish habitats around New Zealand (Chapman 2002, Luque et al. 2007).

This study is also the first record of immature adults of H. spinigera in the intermediate host after Baylis (1931) seriously questioned whether such precocious sexual development existed. Luque et al. (2007) described parasitic nematode larvae from $P$. excavatum from the same location and classified these as Hysterothylacium sp. However, examination of the present specimens and of fig. 2A-C included in Luque et al. (2007) showed clearly that the larval nematodes collected from $P$. excavatum were in fact immature adults of $H$. spinigera identical to the specimens described herein; although it is possible that larval Hysterothylacium sp. also occur in amphipods of Lake Waihola. Both Hedruris androphora and H. ijimai were previously shown to develop into immature adults within isopod intermediate hosts (Anderson 2000). Similarly to H. spinigera, larvae of the newly described species $H e$ druris suttonae also exhibited extreme precocity in their amphipod intermediate host (Brugni and Viozzi 2010). This was suggested to accelerate gamete production in the definitive host (Petter 1971, Hasegawa and Otsuru 1979, Anderson 2000). Only H. androphora and H. suttonae immature adults were previously described and found mor- phologically similar to mature adults (Petter 1971, Brugni and Viozzi 2010). This similitude was also observed in $H$. spinigera between immature adults found in amphipod intermediate hosts and adults from fish definitive hosts. In the case of $H$. spinigera, precocious maturity and rapid gamete production after transmission could have evolved with the use of definitive hosts that have seasonally variable densities.

Here, we describe larval stages (immature adults) of Hedruris spinigera, identify the intermediate host species involved in its life cycle, and present data on prevalence, mean abundance and mean intensity of $H$. spinigera infection in the different species of fish, potential definitive hosts. The results seem to indicate that both intermediate and definitive host distributions may limit the geographical distribution of the parasite. Indeed, hosts and parasites are found in the same type of habitats (coastal fresh and brackish water systems) and likely have geographic ranges broadly overlapping, although geographically exhaustive sampling is needed to verify similarities between host and parasite distributions. We also suggest that $H$. spinigera infection patterns in fish hosts could be due to host suitability rather than the probability of transmission given that all fish species consume the intermediate host Paracorophium excavatum and are therefore exposed to the parasite. As mentioned herein, the anatomy of fish digestive tracts, especially that of the stomach, is likely to play an important role in host suitability for $H$. spinigera although further investigations are needed to test for this hypothesis.

Acknowledgements. We thank Antoine Lecerf (EcoLab CNRS UMR 5245) for comments on an earlier version of the manuscript and Ken Miller (Drawing Office, Department of Zoology, University of Otago) for help on the artwork. This research was supported by a PBRF Research Enhancement grant from the Zoology Department, University of Otago, to Robert Poulin. Fabiano M. Vieira was supported by a Doctoral fellowship from REUNI/UFRRJ (Programa de Apoio à Reestruturação e Expansão das Universidades Federais, Brasil) and Kristin Herrmann by a University of Otago PhD scholarship. José L. Luque was supported by a Research fellowship from CNPq (Conselho Nacional de Pesquisa e Desenvolvimento Tecnológico, Brasil).

\section{REFERENCES}

Altschul S.F., Gish W., Miller W., Myers E.W., Lipman D.J. 1990: Basic local alignment search tool. J. Mol. Biol. 215: 403410.

Anderson R.C. 2000: Nematode Parasites of Vertebrates. Their Development and Transmission. 2nd Ed. CABI Publishing, Wallingford, UK, $672 \mathrm{pp}$.

Appelberg M. 2000: Swedish standard methods for sampling freshwater fish with multi-mesh gillnets. Natl. Board Fish. 1: 1-27.

BAKER M.R. 1986: Revision of Hedruris Nitzsch (Nematoda: Habronematoidea) from aquatic vertebrates of North America. Can. J. Zool. 64: 1567-1572.
BAYLIS H.A. 1931: A species of the nematode genus Hedruris occurring in the trout in New Zealand. Ann. Mag. Nat. Hist., Ser. 10, 7: 105-114

BELL B.D. 1978: Observations on the ecology and reproduction of the New Zealand leiopelmid frogs. Herpetologica 34: 340-354.

Brugni N.L., Viozzi G.P. 2010: A new hedrurid species (Nematoda) from galaxiid fishes in Patagonia (Argentina), and infection of amphipods as intermediate host. J. Parasitol. 96: 109-115.

Bursey C.R., Goldberg S.R. 2000: Hedruris hanleyae n. sp. (Nematoda: Hedruridae) from Hemidactylus garnotii (Sauria: Gekkonidae) from the Cook Islands, Oceania. J. Parasitol. 86: 556-559. 
Bursey C.R., Goldberg S.R. 2007: New species of Hedruris (Nematoda: Hedruridae), Anuracanthorhynchus lutzi (Hamann, 1891) n. comb. and other helminths in Lithobates warszewitschii (Anura: Ranidae) from Costa Rica. Carib. J. Sci. 43: 1-10.

Bush A.O., Lafferty K.D., Lotz J.M., Shostak A.W. 1997: Parasitology meets ecology on its own terms: Margolis et al. revisited. J. Parasitol. 83: 575-583.

Campos A., Carbonell E. 1994: Parasite community diversity in two Mediterranean labrid fishes Symphodus tinca and Labrus merula. J. Fish Biol. 44: 409-413.

Chabaud A.G. 1974: Class Nematoda. Keys to subclasses, orders and superfamilies. In: R.C. Anderson, A.G. Chabaud and S. Willmott (Eds.), CIH Keys to the Nematode Parasites of Vertebrates. Commonwealth Agricultural Bureau, Farnham Royal, United Kingdom, pp. 6-17.

Chabaud A.G. 1975: Keys to the genera of the order Spirurida. Spiruroidea, Habronematoidea and Acuarioidea. In: R.C. Anderson, A.G. Chabaud and S. Willmott (Eds.), CIH Keys to the Nematode Parasites of Vertebrates, Part 2. Commonwealth Agricultural Bureau, Farnham Royal, United Kingdom, pp. 29-58.

Chabaud A.G., Bain O. 1994: The evolutionary expansion of the Spirurida. Int. J. Parasitol. 24: 1179-1201.

Chandler A.C. 1919: On a species of Hedruris occurring commonly in the western newt, Notophthalmus torosus. J. Parasitol. 5: $116-122$.

Chapman M.A. 2002: Australasian species of Paracorophium (Crustacea: Amphipoda): the separate identities of $P$. excavatum (Thomson, 1884) and P. brisbanensis sp. nov. J. R. Soc. N. Z. 32: 203-228.

Clark W.C. 1978: Head morphology and prehensile adaptations in Hedruris spinigera (Nematoda: Spirurida). N. Z. J. Zool. 5: 497501.

Eldon G.A., Greager A.J. 1983: Fishes of the Rakaia lagoon. N. Z. Ministr. Agric. Fish., Fish. Environ. Rep. 30: 1-65.

Floyd R.M., Rogers A.D., Lambshead P.J.D., Smith C.R. 2005: Nematode-specific PCR primers for the $18 \mathrm{~S}$ small subunit rRNA gene. Mol. Ecol. Notes 5: 611-612.

Froese R., Pauly D. 2000: FishBase 2000: Concepts, Design and Data Sources. ICLARM, Los Baños, Laguna, Philippines, 344 pp.

Griffiths W.E. 1976a: Hedruris spinigera (Nematoda: Spiruridae) in stomachs of perch Perca fluviatilis L. N. Z. J. Mar. Freshwater Res. 10: 533-536.

GrifFiths W.E. 1976b: Food and feeding habits of European perch in the Selwyn River, Canterbury, New Zealand. N. Z. J. Mar. Freshwater Res. 10: 417-428.

Hall C.J., Burns C.W. 2002: Environmental gradients and zooplankton distribution in a shallow, tidal lake. Arch. Hydrobiol. 154: 485-497.

Hasegawa H. 1989: Neoentomelas asatoi gen. and sp. n. (Nematoda: Rhabdiasidae) and Hedruris miyakoensis sp. n. (Nematoda: Hedruridae) from skinks of the Ryukyu Archipelago, Japan. Proc. Helminthol. Soc. Wash. 56: 145-150.

Hasegawa H., Otsuru M. 1979: Life history of an amphibian nematode, Hedruris ijimai Morishita, 1926 (Hedruridae). Jpn. J. Parasitol. 28: 89-97.

Hine P.M. 1978: Distribution of some parasites of freshwater eels in New Zealand. N. Z. J. Mar. Freshwater Res. 12: 179-187.

Hine P.M. 1980: Distribution of helminthes in the digestive tracts of New Zealand freshwater eels. 1. Distribution of digeneans. N. Z. J. Mar. Freshwater Res. 14: 329-338.
Hine P.M., Jones J.B., Diggles B.K. 2000: A checklist of parasites of New Zealand fishes, including previously unpublished records. NIWA Technical Report 75, 93 pp.

Horn M.H. 1989: Biology of marine herbivorous fishes. Oceanogr. Mar. Biol. Annu. Rev. 27: 167-272.

IRWIN S.W.B. 1997: Excystation and cultivation of trematodes. In: B. Fried and T.K. Graczyk (Eds.), Advances in Trematode Biology. CRC Press, Boca Raton, Florida, pp. 57-85.

Jellyman D.J. 1989: Occurrence of the nematode Hedruris spinigera in the stomachs of freshwater eels. N. Z. J. Zool. 16: 185-189.

Lagrue C., Poulin R. 2008a: Lack of seasonal variation in the lifehistory strategies of the trematode Coitocaecum parvum: no apparent environmental effect. Parasitology 135: 1-9.

Lagrue C., Poulin R. 2008b: Intra- and interspecific competition among helminth parasites: effects on Coitocaecum parvum lifehistory strategy, size and fecundity. Int. J. Parasitol. 38: 14351444

Luque J.L., Bannock L.M., Lagrue C., Poulin R. 2007: Larval Hysterothylacium sp. (Nematoda, Anisakidae) and trematode metacercariae from the amphipod Paracorophium excavatum (Corophiidae) in New Zealand. Acta Parasitol. 52: 146-150.

McDowall R.M. 1990: New Zealand Freshwater Fishes: a Natural History and Guide. Heinemann Reed MAF Publishing Group, Auckland, New Zealand, $230 \mathrm{pp}$.

Moravec F., Fredensborg B.L., Latham A.D.M., Poulin R. 2003: Larval Spirurida (Nematoda) from the crab Macrophthalmus hirtipes in New Zealand. Folia Parasitol. 50: 109-114.

Nitzsch C.L. 1821: Ascaris. In: J.S. Ersch and J.G. Gruber (Eds.), Allgemeine Enzyklopedie der Wissenschaften und Künste, Leipzig, pp. 6.44-6.49.

Petter A.-J. 1971: Redescription d'Hedruris androphora Nitzsch, 1821 (Nematoda, Hedruridae) et étude de son développement chez l'hôte intermédiaire. Ann. Parasitol. Hum. Comp. 46: 479-495.

Rogers W.P. 1960: The physiology of infective processes of nematode parasite; the stimulus from the animal host. Proc. R. Soc. Lond., Ser. B, 152: 367-386.

Schnabel K.E., Hogg I.D., Chapman M.A. 2000: Population genetic structure of two New Zealand corophiid amphipods and the presence of morphologically cryptic species: implications for the conservation of diversity. N. Z. J. Mar. Freshwater Res. 34: 637-644.

Sharpe R.G., Hims M.M., Harbach R.E., Butlin R.K. 1999: PCRbased methods for identification of species of the Anopheles minimus group: allele-specific amplification and single-strand conformation polymorphism. Med. Vet. Entomol. 13: 265-273.

Stokell G. 1936: The nematode parasites of Lake Ellesmere trout. Trans. Proc. R. Soc. N. Z. 66: 80-96.

STUNKARD H.W. 1953: Life histories and systematics of parasitic worms. Syst. Zool. 2: 7-18.

Thомson G.M. 1922: The Naturalization of Animals and Plants in New Zealand. Cambridge University Press, Cambridge, UK, 607 pp.

Tischler G., Gassner H., Wanzenbock J. 2002: Sampling characteristics of two methods for capturing age- 0 fish in pelagic lake habitats. J. Fish Biol. 57: 1474-1487.

Towns D.R., Daugherty C.H. 1994: Patterns of range contractions and extinctions in the New Zealand herpetofauna following human colonisation. N. Z. J. Zool. 21: 325-339.

Yamaguti S. 1935: Studies on the helminth fauna of Japan. Part 9. Nematodes of fishes, 1. Jpn. J. Zool. 6: 338-386. 